\title{
Remodelling technology transfer
}

\author{
Should inventors control the fate of their own inventions? In the US, most universities think not. But, \\ as Emmanuel Dumont explains, the Jacobs Technion-Cornell Institute at Cornell Tech in New York City \\ bets otherwise.
}

$\mathrm{n}$ n 1787, the Founding Fathers of the US wrote a very concise Constitution. It encompassed only seven articles for a newly formed country where $90 \%$ of people were farmers. Yet, among other fundamental duties, such as collecting taxes and declaring war, there was "The Congress shall have Power... To promote the Progress of Science and useful Arts, by securing for limited Times to Authors and Inventors the exclusive Right to their respective Writings and Discoveries" (Article 1, Section 8). In other words, protecting intellectual property is part of American DNA. Some historians, such as Doron Ben-Atar at Fordham University, see some irony there because only four years after the Constitution was written, Alexander Hamilton presented the Report on Manufactures to Congress where he recommended that the US rewarded those who brought "improvements and secrets of extraordinary value" from abroad. As a result, some Americans were awarded US patents on technologies developed by others in the UK.

Moving forward, several Patent Acts were enacted (in 1790, 1793 and 1836) and the US government took ownership of all intellectual property created with the support of some federal funding. Increased federal spending on research and the Second World War catalysed the growing role of universities in creating intellectual property - the most notable example being the Manhattan Project. From 1935 to 1980, federal funding given to academic research increased by more than $250 \%$, reaching $70 \%$ of research universities' budget in 1980. This turned out to be fruitful in terms of innovation and the US government became overwhelmed by its patent portfolio. In 1978, for example, the General Accounting Office reported that the US government owned 28,000 patents but commercialized less than $5 \%$ of them. To solve this problem, the Bayh-Dole Act was adopted in 1980, giving federally funded small businesses and universities the ownership of the patents they file. The Bayh-Dole Act is widely recognized as the most important piece of intellectual property legislation since the Constitution was written.

This led to the creation of a Technology Transfer Office at many universities. The

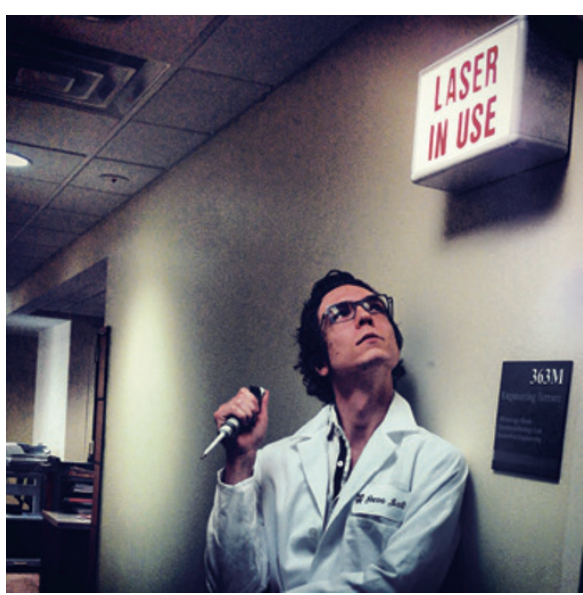

role of such offices is to provide support to faculty members who think their research is patentable; to file, prosecute and litigate patents; and to seek companies to license the patents. Today, Princeton University, Massachusetts Institute of Technology, Columbia University and New York University lead the US in terms of technology transfer, with revenues of over US $\$ 130$ million each in 2012; moreover, between 1991 and 2011 , nearly 59,000 patents were awarded to universities and $80 \%$ had active licenses or licensing options (talk by Orin Herskowitz, Columbia Tech Ventures; http://vimeo. com/110193999). However, when intellectual property is created and a license is granted to a company by a university, inventors usually do not hold any executive position in the company. At most, they are part of the scientific advisory board.

In contrast, the Jacobs Technion-Cornell Institute at Cornell Tech in New York City is now offering postdoctoral research positions in its Runway Program where the Institute automatically provides an exclusive, royaltyfree and non-revocable license to companies formed by Runway fellows in exchange for an equity participation in their company. This is, following the radical decentralization of federal-funded inventions to universities through the Bayh-Dole act, an experiment in further decentralization. It is also an audacious bet, since scientists are experts in their domains but have not usually had a chance to learn about business development and the driving forces of investments, two topics traditionally confined to business schools.

I am currently part of the Runway Program and, in terms of education, the Institute provides an accelerated training in businessrelated matters by inviting prominent industry leaders and investors to campus - it feels like an MBA but without all the social events. We put in practice all the essential steps of starting a company: file a patent, incorporate a company, identify a specific problem solvable by the invention, engage with future customers, quantify this problem in dollar amounts, assemble a team, evaluate competition, build a minimum viable product and raise funding. But, more surprisingly, as scientists, we also learn how to cope with the schizophrenia of our position: our rigorous academic training has taught us to make educated, humble and quantified claims, whereas in the world of start-ups, superlatives are being used with little restriction. On the other hand, the creativity and tenacity required in sustaining daily failure - aka the $\mathrm{PhD}$ training - prove to be valuable skills in surviving the emotional rollercoaster of starting a company.

Having witnessed at Columbia University, where I did my PhD (research from this time is featured on page 166 of this issue), the traditional intellectual property model, and now the new intellectual property model developed at the Institute, I see great value in students and postdoctoral researchers exploring, as part of their curriculum, the commercialization of their research. This would provide scientists and engineers with a greater perspective on their field and a fundamental understanding of job creation and economic welfare. Traditionally, academic researchers focus on publications, to the exclusion of translating federal spending into economic development. Initiatives such as the Institute's Runway Program would help bring more scientists out of their ivory tower.

EMMANUEL L. P. DUMONT is a co-principal investigator in the Runway Program at the Jacobs Technion-Cornell Institute at Cornell Tech, 111 Eighth Avenue, Suite 302, New York, New York 10011, USA and is a co-founder and CEO of a biotechnology company. e-mail: em@jacobs.technion.ac.il 